NSPCC and is for all those who wish to enhance their awareness and skills regarding child protection.

A group of young people working with the Children's Commission ${ }^{11}$ have recently identified 'violence, abuse, and bullying' as their number one problem and priority issue. This should not be a surprise to us, but will we as adults, entrusted with their care, hear what they are telling us? Unless we become more responsive to children and young people the rates of child abuse will remain unchanged and many childhoods damaged irreparably.

\section{Jane H Roberts}

\section{REFERENCES}

1. The Victoria Climbié Inquiry. Report of an inquiry by Lord Laming. Presented to Parliament in 2003. http://www.victoria-climbie-

inquiry.org.uk/finreport/finreport.htm (accessed 5 Aug 2008).

2. Creighton SJ, Tissier J. Child killings in England and Wales. London: NSPCC, 2006.

http://www.nspcc.org.uk/Inform/research/Briefings/ childkillingsinenglandandwales_wda48218.html (accessed 11 Aug 2008).

3. HM Government. Every child matters. London: The Stationery Office, 2003.

4. HM Government. Working together to safeguard children: a guide to inter-agency working to safeguard and promote the welfare of children. London: The Stationery Office, 2006.

5. Cawson, P, Wattam, C, Brooker, S, Kelly, G. Child maltreatment in the UK: a study of the prevalence of child abuse and neglect. London: 2000, NSPCC.

6. Home Office. Criminal statistics: England and Wales 2001. London: Stationery Office, 2002.

7. Dorling D, Rigby J, Wheeler B, et al. Poverty, wealth and place in Britain, 1968 to 2005. Bristol: Published for the Joseph Rowntree Foundation by The Policy Press, 2007.

8. Pool R, Geissler W. Medical anthropology. Open University Press: London, 2005.

9. Heath I. Let's get tough on the causes of inequality. BMJ 2007; 334: 1301.

10. Royal College of General Practitioners \& The National Society for the Prevention of Cruelty to Children. Safeguarding children and young people in general practice: A Toolkit. London: RCGP, 2007.http://www.rcgp.org.uk/PDF/CIR_Toolkit\%20d ocument $\% 20$ final\%20edit.pdf (accessed 5 Aug 2008)

11. The Children's Commission. 11 Million - The Children's commissioner for England. London: The Children's Commission, 2008.

http://www.11million.org.uk (accessed 5 Aug 2008).

\title{
Good to see you back 007
}

\section{DEVIL MAY CARE: SEBASTIAN FAULKS \\ Penguin, 2008}

HB, 320 pages, £18.99, 9780718153762

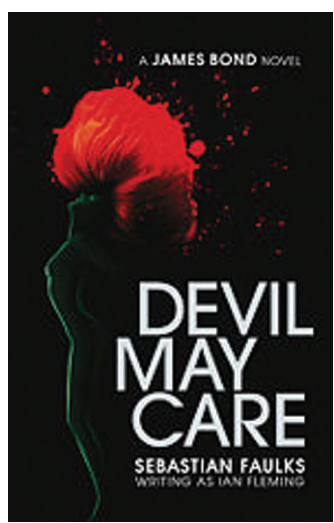

Sebastian Faulks is reported to have agreed to write Devil May Care over lunch and a fabulous Burgundy. Very Bond, who consumes heroic quantities of Dom Perignon, Stolichnaya, and Chateau Batailley, as well as martinis by the jugful. Most of the other Bond essentials are woven into this ripping yarn - the gorgeous girl who is not quite what she seems, the psychopathic baddie bent on world domination or destruction, the miraculous escapes from death and mutilation.

In the new Bond, however, the bad guys have nearly all the toys and James is notably underdressed, as well as underpowered (the Walther PPK is now regarded as a hairdresser's gun, the firearms equivalent of a BMW Z3). Q doesn't make an appearance, but $\mathrm{M}$ and Moneypenny are there, dependable as ever.

Faulks has set Devil May Care in the Middle East during the Cold War and captures both Fleming's journalist's prose style and the period milieu beautifully.

The disaffected lunatic at the centre of the plot disparages Britain's imperial adventures and at one point deprives Bond of food because of the Irish potato famine. The 100th anniversary of Fleming's birth (1908-1964) has generated a number of analyses of Bond's character - filling the void after a war which we won but come out secondbest, reconnecting with Empire - and there are elements of the Great Game between the British and the Russian Empire in Devil May Care, as well as telling echoes and parallels with present day concerns, including urban alienation, opiate addiction and the special relationship between Britain and the US.

Faulks' carefully structured plot and expert writing rarely falter, although there are a few Google moments where a plane or a car has been over-researched. There are some truly memorable scenes and terrific locations. Faulks also does a nice line in torture. The book gathers pace effortlessly and the last 100 pages are a real roller coaster. Great days.

\section{Roger Jones}

DOI: 10.3399/bjgp08X342093 